Teologia I Moralność

Volumen 11(2016), numer 1(19)

doi: 10.14746/TIM.2016.19.1.16

\title{
KRZYSZTOF NIEWIADOMSKI
}

Wyższe Seminarium Duchowne Braci Mniejszych Kapucynów

w Krakowie

\section{Wolność osoby ludzkiej w średniowiecznych rozważaniach o małżeństwie niewolników. \\ Na podstawie Summy teologicznej św. Tomasza z Akwinu oraz Ordinatio bł. Jana Dunsa Szkota}

\section{Freedom of Human Being in the Medieval Discussion on Slaves Marriage Based on the Summa} Theologiae of St. Thomas Aquinas and Ordinatio of John Duns Scotus

\section{WSTĘP}

Obok różnych przeszkód małżeńskich teologowie średniowieczni rozważali zagadnienie ważności małżeństwa niewolników. Istnienie takiego problemu było zrozumiałe, instytucja niewolnictwa funkcjonowała bowiem w tym czasie oficjalnie w społeczeństwie. Tymczasem jest oczywiste, że do wypełnienia obowiązków małżeńskich jest potrzebna pewna przestrzeń wolności osobistej. U podstaw zarówno samego postawienia kwestii przeszkody stanu niewolniczego do zawarcia małżeństwa, jak i jej rozwiązania, leży określona koncepcja osoby ludzkiej, jej wolności i miejsca w Kościele oraz w społeczeństwie. Rozważane zagadnienie stanowi ciekawe zestawienie stanu zewnętrznego odebrania wolności, jakim jest niewolnictwo, z darem własnej wolności dla drugiej osoby w małżeństwie. Można przewidywać, że analiza dzieł teologii średniowiecznej, jakimi są Summa teologiczna św. Tomasza z Akwinu (ok. 1225-1274) i Ordinatio bł. Jana Dunsa Szkota (ok. 1266-1308), pozwoli poznać założenia antropologiczne wybitnych teologów okresu scholastyki.

Jak wiadomo, cytowana w artykule kwestia pięćdziesiąta druga Summy teologicznej, traktująca o małżeństwie niewolników, należy do jej części powstałej już po śmierci Akwinaty. Jest ona jednak dosłowną kopią jego Komentarza do Sentencji Piotra Lombarda, mianowicie kwestii pierwszej distinctio trzydziestego szóstego, tomu czwartego. Jedynie piąty artykuł tego questio, dotyczący prze- 
szkody wieku, został przeniesiony w Summie teologicznej do innej, pięćdziesiątej ósmej kwestii. Przy rozważaniu problemu postawionego w artykule możliwe byłoby więc odwołanie się także do Komentarza do Sentencji Piotra Lombarda, jednak obecność tego tekstu w Summie teologicznej świadczy o jego pozytywnej recepcji przez teologów współczesnych św. Tomaszowi, co stanowi dodatkowy argument za przyjętym sposobem cytowania. Ordinatio natomiast jest największym i samodzielnym dziełem bł. Jana Dunsa Szkota, zwanego Doktorem Subtelnym, czołowego przedstawiciela teologii franciszkańskiej.

\section{SUMMA TEOLOGICZNA AKWINATY O MAŁŻEŃSTWIE NIEWOLNIKÓW}

Temat małżeństwa niewolników jest podjęty w Summie teologicznej w zagadnieniu pięćdziesiątym drugim tak zwanego Supplementum ${ }^{1}$. Kwestia ta jest zatytułowana: „O przeszkodzie stanu niewolniczego”. Jej kolejne artykuły stanowią odpowiedzi na cztery pytania: Czy stan niewolniczy jest przeszkodą małżeńską? Czy niewolnik bez pozwolenia swego pana może zawrzeć małżeństwo? Czy ktoś, ożeniwszy się, może oddać się w niewolę bez pozwolenia żony? Czy dzieci niewolników mają być również niewolnikami? Do tematu niniejszej publikacji odnoszą się trzy pierwsze artykuły.

Artykuł pierwszy zawiera najpierw argumenty potwierdzające tezę, że stan niewolniczy nie jest przeszkodą do zaistnienia małżeństwa. Pierwszy z nich to po prostu stwierdzenie, że gdyby taka przeszkoda istniała, nie byłyby możliwe małżeństwa niewolników. Ich istnienie, przy założeniu wartości takich związków, praktycznie falsyfikuje tezę o niewolnictwie jako przeszkodzie małżeńskiej. Drugi argument to stwierdzenie przewagi prawa natury nad tym, co jest mu przeciwne. Małżeństwo jest zgodne z prawem natury, niewolnictwo zaś nie, jak pisze św. Grzegorz Wielki: „Gdy człowiek chce panować nad innym człowiekiem, sprzeciwia się naturze"2. Akwinata dodatkowo udowadnia to twierdzenie za pomoca cytatu z Pisma Świętego, gdzie Stwórca przykazał człowiekowi, by „panował nad rybami morskimi, nad ptactwem powietrznym, nad bydłem, nad całą ziemią i nad wszelkim zwierzęciem naziemnym" (Rdz 1,26), ale nie nad bliźnim. Trzeci argument jest natury prawniczej - niewolnictwo mogłoby uniemożliwiać małżeństwo na mocy prawa naturalnego albo pozytywnego, ale ponieważ prawo pozytywne powinno wypływać z naturalnego, nie może ono ustanowić takiej przeszkody. Święty Grzegorz Wielki twierdzi bowiem, że „wszyscy ludzie są równi”’3, podobnie Digesta uznają, że niewolnictwo nie wynika z prawa natury ${ }^{4}$. q. 52 .

${ }^{1}$ Tomasz z Akwinu, Suma teologiczna. Małżeństwo, t. 32, thum. F.W. Bednarski, Londyn 1982,

${ }^{2}$ Grzegorz Wielki, Księga reguły pasterskiej, tłum. J. Czuj, Poznań 2009, s. 50.

${ }^{3}$ Tamże s. 49.

${ }^{4}$ Digesta Justyniańskie. Księga Pierwsza, tłum. B. Szolc-Nartowski, Warszawa 2007, s. 15; s. 52. 
Prawo zaś pozytywne wypływa z naturalnego, jak uczy Cyceron ${ }^{5}$. Czwarty argument opiera się na rozumowaniu, że gdy coś jest przeszkodą małżeńską, jest nią bez względu na to, czy jest się tego świadomym, czy też nie, jak to widać na przykładzie pokrewieństwa. Tymczasem stan niewolniczy danej osoby, znany temu, kto z nią zawiera małżeństwo, nie stanowi jego przeszkody. Piąty argument zawiera stwierdzenie, że błąd może odnosić się zarówno do stanu niewolniczego, jak i do stanu wolnego, gdy ktoś człowieka wolnego uważa za niewolnika, lecz wolność nie jest przeszkodą małżeńską. Nie jest więc nią także stan niewoli. Ostatni argument opiera się na analogii do sytuacji choroby trądu, nieuleczalnej w średniowieczu. Choroba ta bardziej niż stan niewolniczy sprawia, że współżycie małżeńskie staje się uciążliwe i bardziej niż niewola sprzeciwia się dobru potomstwa, lecz trąd nie jest uznawany za przeszkodę małżeńską.

$\mathrm{Z}$ drugiej jednak strony w średniowiecznym zbiorze praw zwanym Dekretaliami $^{6}$ znajduje się stwierdzenie, że błąd co do stanu niewolniczego jest przeszkodą zawarcia małżeństwa i unieważnia już zawarte. Ponadto inny przeciwny argument opiera się na fakcie, że małżeństwo odnosi się do dóbr, które z natury są godne pożądania. Natomiast niewolnictwo ze swej natury budzi odrazę, a więc sprzeciwia się małżeństwu i stanowi jego przeszkodę.

Rozwiązanie podane w Summie teologicznej opiera się na zobowiązaniu przez umowę ślubną do spełniania powinności małżeńskiej. Jeśli ktoś nie jest w stanie tego czynić, wówczas nieznajomość tej przeszkody u męża lub żony powoduje nieważność małżeństwa. Brak zdolności do odbycia stosunku seksualnego powoduje całkowitą niemożność spełniania powinności małżeńskiej, a niewolnictwo nie pozwala tu na pełną swobodę. Dla św. Tomasza tylko nieznana narzeczonemu niemożność odbycia stosunku jest przeszkodą małżeńską, a nie taka, której jest on świadomy, podobnie tylko nieznany stan niewolniczy?

Po tym rozwiązaniu następuje, jak zwykle w Summie teologicznej, odpowiedź na poszczególne trudności podane na początku artykułu. Rozwiązanie pierwszej trudności: niewolnictwo sprzeciwia się małżeństwu ze względu na niemożliwość swobodnego spełniania czynności, do której ktoś się zobowiązuje, i ze względu na potomstwo, którego położenie staje się gorsze z powodu niewolniczego stanu rodziców. Ponieważ jednak każdemu wolno dobrowolnie zgodzić się na umniejszenie tego, co mu się należy, dlatego jeśli przyszły mąż lub żona wie o stanie niewolniczym osoby, z którą chce zawrzeć małżeństwo, zawiera je ważnie.

${ }^{5}$ Marcus Tullius Cicero, O inwencji retorycznej. De inventione, thum. K. Ekes, Warszawa 2013, s. 234-237.

${ }^{6}$ Por. Raymundus de Pennaforte, Decretales D. Gregorii Papae IX.: suae integritati vna cum glossis restitutae, Romae 1582, lb 4, tit. 9, cap. 4.

${ }^{7}$ Por. Tomasz z Akwinu, Suma teologiczna, dz. cyt., q. 52, a. 1. 
Rozwiązanie drugiej trudności: niewolnictwo przeciwstawia się tzw. pierwszemu zamierzeniu natury, a nie drugiemu, co jest dopuszczalne. Na przykład wszelkie zepsucie, słabość czy starzenie się sprzeciwia się naturze, która dąży do zachowania bytu ${ }^{8}$, jednak nie sprzeciwia się wtórnemu zamierzeniu natury, która nie mogąc zachować bytu w jednej istocie, zachowuje ją w drugiej, powstającej dzięki zniszczeniu innej. Podobnie niewolnictwo sprzeciwia się pierwszemu zamierzeniu natury, ale nie wtórnemu, gdyż naturalny rozum (naturalis ratio) nakłania do tego, czego także pożąda natura, a mianowicie by każdy człowiek był dobry. Ze względu jednak na to, że ludzie grzesza, natura skłania do wymierzenia kary za grzech. W ten sposób niewolnictwo powstało jako kara za zło. Nie ma w tym niczego niestosownego, że to, co sprzeciwia się naturze, stanowi przeszkodę tego, co jest z nią zgodne.

Kolejna trudność zostaje rozwiązana przez następujące rozumowanie: prawo naturalne wymaga, aby wymierzać kary za winy i by nie karać niewinnego. Natomiast prawo pozytywne ma określić, jaką karę należy wymierzyć zależnie od okoliczności osoby i winy. Dlatego niewolnictwo, które jest karą, zostało wyznaczone przez prawo pozytywne, ale pochodzi z prawa naturalnego. Również mocą prawa pozytywnego niewolniczy stan jednego z narzeczonych, nieznany drugiemu, został zaliczony do przeszkód małżeńskich w tym celu, by nie karać niewinnego, gdyż związanie się węzłem małżeńskim z niewolnikiem byłoby karą dla współmałżonka.

Rozwiązanie czwartej trudności: niektóre przeszkody sprawiaja, że małżeństwo jest niedozwolone. Ponieważ nie zależy to od człowieka, czy coś jest niedozwolone lub dozwolone, ale od prawa, któremu wola winna się poddać, dlatego ani nieznajomość tego rodzaju przeszkody, która uniemożliwia dobrowolność, ani jej znajomość, nie mają znaczenia dla wartości małżeństwa. Taką przeszkodą jest np. powinowactwo czy węzeł małżeński. Są jednak inne przeszkody, które sprawiają, że mąż lub żona nie mogą wypełnić powinności małżeńskiej. Ponieważ jednak od czyjejś woli zależy wymaganie, by ktoś spełnił powinność względem niego, dlatego takie przeszkody, jeśli są znane, nie sprawiają nieważności małżeństwa. Natomiast powodują ją gdy ta nieznajomość uniemożliwia dobrowolność zgody na małżeństwo. Tego rodzaju przeszkodami są stan niewolniczy oraz niemożność odbycia stosunku małżeńskiego. Ze względu na to, że te przeszkody same przez się mają w swojej istocie coś, co się sprzeciwia małżeństwu, wylicza się je osobno, niezależnie od przeszkody błędu.

Na piąty argument przeciwny autor odpowiada, że wolność nie sprzeciwia się aktom małżeńskim. Nieznajomość jej nie stanowi więc przeszkody małżeńskiej. Co do szóstego argumentu św. Tomasz stwierdza, że trąd nie jest przeszkodą dla aktów małżeńskich, gdyż trędowaci mogą dowolnie spełniać powinność

\footnotetext{
${ }^{8}$ Por. Arystoteles, O niebie, thum. P. Siwek, Warszawa 1980, s. 71.
} 
małżeńska, chociaż choroba ta obciąża małżeństwo ze względu na wtórne następstwa. Trąd, w przeciwieństwie do stanu niewolniczego, nie stanowi więc przeszkody małżeńskiej9.

Artykuł drugi jest odpowiedzią na pytanie: Czy niewolnik może zawrzeć małżeństwo bez pozwolenia swego pana? Argumenty przeciwne są następujące: po pierwsze, nikt nie może dać tego, co należy do drugiej osoby bez jej pozwolenia. Tymczasem „niewolnik jest rzeczą swego pana”, jak mówi Arystoteles ${ }^{10}$. Po drugie, niewolnik musi słuchać swego właściciela (Ef 6,5; Kol 3,22), a ten może mu zakazać zawierania ugody małżeńskiej. Ponadto, po zawarciu małżeństwa niewolnik jest zobowiązany, także mocą prawa Bożego, do spełniania powinności małżeńskiej (1 Kor 7,3), lecz właściciel może zażądać od niewolnika realizacji jakiegoś zadania, którego nie mógłby wykonać w tym czasie, kiedy żona żąda spełnienia powinności małżeńskiej. Jeśliby więc niewolnik zawarł małżeństwo bez pozwolenia swojego pana, pozbawiłby go bez jego winy należnej mu służby. Jednak według autora Supplementum nie byłoby właściwe.

Po trzecie, właściciel może sprzedać swego niewolnika do innego kraju, do którego żona nie może się udać, czy to z powodu słabego zdrowia, czy to z powodu niebezpieczeństwa dla wiary, na przykład, gdy ktoś sprzeda niewolnika innowiercom, wreszcie wskutek braku zgody właściciela, kiedy żona jest również niewolnicą. Nastapiłoby więc rozbicie małżeństwa, a to nie powinno mieć miejsca. Po czwarte, ważniejsze jest zobowiązanie się do spraw Bożych niż powinność oddania się żonie. Skoro niewolnik bez zgody właściciela nie może wstapić do zakonu lub do stanu duchownego, tym bardziej nie może zawrzeć związku małżeńskiego bez pozwolenia pana.

Jednak z drugiej strony św. Paweł pisze: „nie ma już niewolnika ani człowieka wolnego [...] wszyscy bowiem jesteście kimś jednym w Chrystusie Jezusie" (Gal 3,28). Wynika $\mathrm{z}$ tego, że w wierze chrześcijańskiej ludzie wolni i niewolnicy mają tę samą możliwość zawierania małżeństwa. Ponadto niewolnictwo jest ustanowione przez prawo pozytywne, a małżeństwo przez prawo Boże, które stoi ponad prawem ludzkim. Dlatego w odpowiedzi na podane uprzednio wattpliwości Akwinata przypomina, że sprawiedliwe prawo pozytywne pochodzi z prawa naturalnego. Niewolnictwo więc, ustanowione przez prawo pozytywne, nie może sprzeciwiać się prawu naturalnemu. Niewolnik, podobnie jak nie podlega panu w takich sprawach, jak dobrowolne jedzenie, spanie i tym podobne rzeczy, niezbędne do zachowania życia, tak samo nie podlega mu, gdy chodzi o dobrowolne zawarcie małżeństwa ${ }^{11}$.

Rozwiązanie pierwszej z trudności: niewolnik jest własnością pana w sprawach dodanych do zadań naturalnych, a w tych wszyscy ludzie są równi. W związku

\footnotetext{
${ }^{9}$ Por. Tomasz z Akwinu, Suma teologiczna, dz. cyt., q. 52, a. 1, ad. 1-5.

${ }^{10}$ Arystoteles, Polityka, thum. L. Piotrowicz, Warszawa 2002, s. 21.

${ }^{11}$ Por. Tomasz z Akwinu, Suma teologiczna, dz. cyt., q. 52, a. 2.
} 
z tym, niewolnik może dać prawo kobiecie do aktów małżeńskich bez zgody swego właściciela. Rozwiązanie drugiej trudności: niewolnik winien słuchać właściciela we wszystkim, co ten godziwie może nakazać. Otóż pan, podobnie jak nie może zakazać niewolnikowi jedzenia lub spania, tak też nie może zakazać mu zawarcia małżeństwa. Gdyby to uczynił, niewolnik nie ma obowiązku posłuszeństwa. Rozwiązanie trzeciej wątpliwości: jeśli niewolnik zawarł małżeństwo za zgodą właściciela, musi spełnić powinności małżeńskie wobec żony, pomijając wykonanie służby na rzecz pana. Ten bowiem, pozwalając mu na małżeństwo, tym samym pozwolił na wszystko, czego ono wymaga. Natomiast jeśli niewolnik zawarł małżeństwo bez wiedzy właściciela lub mimo jego sprzeciwu, nie ma obowiązku spełnienia powinności małżeńskiej, lecz raczej niewolnik ma słuchać swego pana, jeśli tych dwóch obowiązków nie da się pogodzić. Jednak w tych sprawach trzeba uwzględnić wiele szczegółów, a więc niebezpieczeństwo dla czystości zagrażające żonie, trudności w wykonywaniu służby z powodu spełniania powinności małżeńskich itp. Należy więc dobrze rozważyć, kogo należy posłuchać: właściciela czy żony.

Odpowiedź na czwartą wątpliwość: należy przymusić właściciela, by nie sprzedawał niewolnika w taki sposób, który utrudniłby mu spełnianie obowiązków małżeńskich. Co do piątej wątpliwości: wstąpienie do zakonu i przyjęcie święceń kapłańskich zobowiązuje do poświęcenia całego czasu na służbę Bożą. Tymczasem małżonkowie nie zawsze są zobowiązani spełniać powinność małżeńską, ale tylko w odpowiednim czasie. Ponadto, kto wstępuje do zakonu lub przyjmuje święcenia, obliguje się do pewnych spraw związanych z tymi zadaniami, wypływających z prawa naturalnego. Natomiast ci, którzy zawierają związek małżeński, zobowiązują się do tych właśnie zadań, niepodlegających panu, w przeciwieństwie do owych spraw dołączonych, które mu podlegaja.

W trzecim artykule autor rozważa wątpliwość: Czy ktoś po zawarciu małżeństwa może sprzedać samego siebie w niewolę? Najpierw podaje argumenty przeciw takiej tezie. Po pierwsze, mąż, stając się niewolnikiem, czyni to ze szkodą dla małżeństwa, a przynajmniej z krzywdą dla żony. Takie więc zaprzedanie się w niewolę nie powinno być ważne. Po drugie, dwie wartości uprzywilejowane przez prawo przeważają nad jedną nieuprzywilejowaną. Małżeństwo i wolność są uprzywilejowane przez prawo ${ }^{12}$ i sprzeciwiają się niewolnictwu, które nie cieszy się względami prawa. Po trzecie, w małżeństwie mąż i żona mają równe prawa. Żona zaś nie może pójść na służbę bez zgody męża, a więc także mąż bez zgody żony. Po czwarte to, co w porządku naturalnym stanowi przeszkodę powstania jakiejś rzeczy, niszczy już powstałą. Niewolniczy stan męża, nieznany żonie, jest przeszkodą zawarcia małżeństwa. Gdyby więc ten stan nastąpił po ślubie, dokonałby rozbicia małżeństwa.

${ }^{12}$ Por. Raymundus de Pennaforte, Decretales..., dz. cyt., lb 2, tit. 27, cap. 26. 
Jednak z drugiej strony każdy może dać drugiemu to, co należy do niego. Skoro mąż jest panem siebie, będąc wolny, może dać prawo do siebie komuś innemu. Ponadto niewolnik może wbrew woli pana pojąć żonę. $Z$ tego samego powodu może poddać się panu wbrew woli swojej żony. W odpowiedzi autor Summy teologicznej stwierdza, że mąż jest poddany żonie jedynie w sprawach odnoszących się do aktu małżeńskiego, gdyż w tej sprawie są równi, zaś stan niewolniczy nie rozciaga się na nią. Dlatego mąż wbrew woli swej żony może oddać się w niewolę komuś innemu, nie rozrywając małżeństwa, gdyż żadna przeszkoda występująca już po zawarciu małżeństwa nie może go rozwiązać1 ${ }^{13}$.

Odpowiedź na pierwszą wątpliwość: za krzywdę wyrządzoną innej osobie powinien ponieść szkodę ten, kto ją wyrządzil, a nie ten, komu jest wyrządzona. Jeśli więc mąż, krzywdząc żonę, oddał się komuś innemu w niewolę, ponosi szkodę, tracąc bezcenne dobro wolności. Nie wolno mu natomiast tym czynem uszczuplać praw żony, a więc będzie nadal zobowiązany spełniać powinność małżeńską oraz wszystkie inne obowiązki. Rozwiązanie drugiej trudności: ze względu na to, że niewolnictwo sprzeciwia się małżeństwu, a małżeństwo ma nad nim przewagę, niewolnik winien spełnić powinności małżeńskie, nawet wbrew woli pana. Rozwiązanie trzeciej trudności: gdy chodzi o powinność małżeńską oraz te wszystkie sprawy, które dotyczą natury, mąż i żona mają równe prawa. Jednak w sprawach zarządzania domem i tym podobnych mąż jest głową żony (1 Kor 11,3; Ef 5,23) dlatego, według św. Tomasza, winien ją karcić, a nie na odwrót. Żona nie może więc zaprzedać się w niewolę bez zgody męża. Rozwiązanie czwartej trudności: wytworzenie rzeczy zniszczalnych może być udaremnione przez wiele przeszkód, niezdolnych jednak do zniszczenia już wytworzonej rzeczy. Gdy jednak chodzi o rzeczy mające wieczną trwałość, mogą zaistnieć przeszkody uniemożliwiające ich powstanie, ale niezdolne do ich zniszczenia. Tak też jest $\mathrm{z}$ małżeństwem, które jest węzłem dozgonnym ${ }^{14}$.

\section{OPINIA BŁ. JANA DUNSA SZKOTA W SPRAWIE MOŻLIWOŚCI ZAWIERANIA MAŁŻEŃSTWA PRZEZ NIEWOLNIKÓW}

W czwartej księdze swojego dzieła Ordiantio, w kwestii pierwszej trzydziestej szóstej dystynkcji, Jan Duns Szkot pyta: „Czy stan niewoli nie pozwala na małżeństwo?” Na początku przytacza on argumenty potwierdzające pozytywną odpowiedź na postawione pytanie: Nikt nie może dać cudzej własności. Osoba sługi należy do pana według Polityki Arystotelesa ${ }^{15}$. Ponadto profesja zakonna cieszy się większym uznaniem niż ziemskie małżeństwo, lecz niewolnik nie może

\footnotetext{
${ }^{13}$ Por. Tomasz z Akwinu, Suma teologiczna, dz. cyt., q. 52, a. 3.

${ }^{14}$ Por. tamże, a. 3, ad. 1-4.

${ }^{15}$ Por. Arystoteles, Polityka, dz. cyt., s. 29.
} 
złożyć profesji zakonnej bez zgody pana. Dlatego nie może także zawrzeć małżeństwa ${ }^{16}$. Przeciwko tezie Szkot powołuje się na prawo kościelne, a konkretnie Decretales D. Gregorii Papae IX ${ }^{17}$, pozwalające na takie małżeństwo.

Doktor Subtelny zauważa, że istnieją dwie rzeczy, które najpierw trzeba zbadać w rozważanej kwestii: Jak zostało wprowadzone niewolnictwo i czy przeszkadza małżeństwu? Co do pierwszego z postawionych pytań Jan Duns Szkot stwierdza, że według prawa natury każdy rodzi się wolny. Jednak niewola, albo bardziej właściwie podległość synowska względem ojca, również wynika z prawa naturalnego, np. posłuszeństwo synowskie odnośnie do nauki, bowiem według Etyki Arystotelesa syn ma od ojca byt i naukę ${ }^{18}$. To natomiast niewolnictwo, o którym mowa - według którego pan może sprzedać niewolnika jak zwierzę, o czym mówi Arystoteles w Polityce ${ }^{19}$, że niewolnik nie może wykonywać aktu cnoty przez to, że należy w związku z nakazem pana wykonywać akty służebne - nie jest wprowadzone inaczej niż jakimś prawem pozytywnym ${ }^{20}$.

Jednak czy taka zależność jest sprawiedliwa? Duns Szkot odpowiada, że ta niegodna (vilis) podległość może być wprowadzona sprawiedliwie jedynie na dwa sposoby. Pierwszy sposób, gdy ktoś dobrowolnie siebie podporządkował takiemu poddaństwu. Chociaż to byłoby nierozsądne, a nawet - być może - przeciw prawu natury, że człowiek zrezygnowałby ze swojej wolności, gdy jednak zaistniało, należy służyć panu, ponieważ jest to sprawiedliwe. Inny sposób, jeśli ktoś sprawiedliwie panując nad wspólnota, widząc kogoś tak bardzo obciążonego wadami, że jego wolność szkodziłaby jemu samemu i społeczności, może zarówno sprawiedliwie ukarać go niewolą, jak i sprawiedliwie może go skazać na śmierć w pewnych przypadkach dla dobra wspólnoty ${ }^{21}$.

Jeśli ktoś mówiłby, że jest trzecia przyczyna niewolnictwa, mianowicie, jeśli schwytany na wojnie byłby ocalony i tak uratowany od śmierci stałby się niewolnikiem przeznaczonym do służby, według Dunsa Szkota nie wydaje się to w sposób oczywisty sprawiedliwe. Chociaż bowiem ten, kto schwytał jeńca, mógł zabić schwytanego, jeśli prowadził sprawiedliwą wojnę obronną, nie zaś inwazję, i ten nie ustępowałby zaciętością przeciw broniącym się, jednak skoro przestaje być zaciekły, co jest w woli tego schwytanego, nieludzkie wydaje się nakładanie na niego kary przeciw prawu natury. Nie ma bowiem takiej racji,

${ }^{16}$ Por. Jan Duns Szkot, Ordinatio, Opera Omnia, t. 13, Civitas Vaticana 2011, nr 1-4.

${ }^{17}$ Por. tamże, nr 5; Por. Raymundus de Pennaforte, Decretales..., dz. cyt., lb. IV, tit. 9, cap. 1 : Servus, contradicente domino, matrimonium contrahere potest; sed propter hoc non liberatur a servitiis domino debitis.

${ }^{18}$ Arystoteles, Etyka nikomachejska, w: Dzieła wszystkie, t. 5, tłum. D. Gromska, Warszawa 1996, s. 251-253.

${ }^{19}$ Por. Arystoteles, Polityka, dz. cyt., s. 46.

${ }^{20}$ Por. Jan Duns Szkot, Ordinatio, dz. cyt., nr 19.

${ }^{21}$ Por. tamże, nr 20-22. 
ponieważ w tym przypadku stałby się posłuszny i darowaną wolność wykorzystał właściwie 22 .

Można spierać się z pierwszą częścią argumentacji, mianowicie że niewolnictwo nie jest przeciw prawu natury, gdyż według Polityki Arystotelesa: „Sprawny umysłem powinien rządzić, silny fizycznie powinien służyć" ${ }^{23}$. Niektórzy zaś są naturalnie sprawni umysłowo, dlatego naturalnie zdatni do panowania, inni mniej mądrzy i mocniejsi ciałem, dlatego naturalnie powinni być sługami. Duns Szkot odpowiada, że nie dotyczy to niewolnictwa, lecz tylko zależności politycznej, przez którą człowiek niższy jest podporządkowany wyższemu, nie tak jednak jak nieożywiony przedmiot, lecz tak jak mniej sprawny umysłem jest zarządzany przez tego, który jest zdolniejszy ${ }^{24}$.

Opierając się na prawie posiadacza, można spierać się również z tezą, że każde niewolnictwo jest niesprawiedliwe. Jest to argumentacja przeciw drugiej części powyższych rozważań, dowodzących niesprawiedliwości prawa pozytywnego o niewolnictwie. Rozważania te opierają się na założeniu, że to, co jest przeciw prawu natury, nie może stać się sprawiedliwe, także długi czas trwania nie ratyfikuje przestępstw, lecz jeszcze bardziej stają się godne potępienia, każda zaś podległość inna od dwóch wyżej wspomnianych przypadków ${ }^{25}$ jest niesprawiedliwa i przeciw naturze. Dlatego z powodu żadnej długotrwałości nie wydaje się usprawiedliwione, że właściciel panuje nad niewolnikami. Szkot odpowiada tu, że prawo (ius) może być nabyte, jeśli zdarzyłyby się te warunki, jakie ustalają prawa, to jest, że ktoś nabyłby własność sprawiedliwie i byłby posiadaczem w dobrej wierze, i bez przerwy czasowej określonej przez prawo. Jednak dotyczy to posiadania, nie niewolnictwa, bowiem nie można mówić o tej samej treści (ratio) co do prawa natury w przypadku posiadania złota i niewolnika. Dlatego byłoby trudno usprawiedliwiać przez przepis prawa, że tacy słudzy są zatrzymani, chyba że byłoby przyjęte, że przez poprzednio wspomniane dwa sposoby byliby uczynieni niewolnikami od początku ${ }^{26}$.

Można także zastanawiać się, dlaczego apostoł poleca niewolnikom posłuszeństwo swoim panom, jeśli jest negowane prawo do posiadania niewolników ${ }^{27}$ ? Szkot odpowiada, że wiele obowiązków jest niesprawiedliwych, które po wprowadzeniu muszą być zachowywane. Dlatego apostoł, dowodząc, że niewolnictwo według niego nie jest godne pochwały ani o wiele bardziej trzymanie kogoś w tym stanie, mówi: „Jeśli zostałeś powołany jako niewolnik, nie troskaj się, lecz jeśli możesz stać się wolnym, raczej wykorzystaj swoją niewolę" $(1 \text { Kor 7,21 })^{28}$.

\footnotetext{
${ }^{22}$ Por. tamże, nr 23.

${ }^{23}$ Por. Arystoteles, Polityka, dz. cyt., s. 23-24.

${ }^{24}$ Por. Jan Duns Szkot, Ordinatio, dz. cyt., nr 24.

${ }^{25}$ Dobrowolne oddanie się w niewolę albo kara za przestępstwo.

${ }^{26}$ Por. Jan Duns Szkot, Ordinatio, dz. cyt., nr 25.

${ }^{27}$ Ef 6,5; Kol 3,22.

${ }^{28}$ Por. Jan Duns Szkot, Ordinatio, dz. cyt., nr 26.
} 
Co do drugiego pytania postawionego na poczattku rozważanej kwestii (czy stan niewoli przeszkadza małżeństwu), można spotkać się z opinią, że niewolnik może zawrzeć małżeństwo wbrew woli pana i to wynika z pierwszej części tego rozważania: małżeństwo bowiem jest z prawa natury. Niewolnictwo zaś nie pochodzi z prawa natury, lecz jest bardziej przeciwko niemu, co zaś jest z prawa natury, nie jest usuwane przez coś innego, co wynika tylko z prawa pozytywne$\mathrm{go}^{29}$. Podawana jest natomiast inna racja: niewolnik nie należy tak bardzo do swego pana, jak jest osobą wolną w świetle prawa, co do aktów naturalnych, odnoszących się do zachowania jednostki. Jest oczywiste, że może używać środków koniecznych do życia; więc przez podobieństwo $\left(\right.$ a simili $\left.^{30}\right)$, odnosi się to do aktów związanych z zachowaniem gatunku. Wniosek jest dowiedziony, bowiem zachowanie gatunku, $\mathrm{z}$ uwagi na to, że jest większym dobrem natury niż zachowanie jednostki, bardziej wynika z prawa natury ${ }^{31}$.

Te dwie racje mogą być uchylone. Pierwsza: bowiem zobowiązanie, które nie jest z prawa naturalnego, słusznie może przeszkadzać jakiejś wolności, która należy się komuś z prawa natury. Przykład: niewątpliwie, jeśli ktoś z prawa naturalnego nie ma wobec drugiego zobowiązań, to jednak jeśli ślubuje mu posłuszeństwo, musi go słuchać. Szkot twierdzi, że małżeństwo nie jest z prawa naturalnego inaczej niż wtórnie (secundario), a w każdym wypadku pochodzi z prawa natury (nawet pierwotnie) oddawanie każdemu, co należy do niego. Wobec tego przez zobowiązanie niewolnik czyni sobie pana, będąc zmuszonym oddać mu, co jest jego, i powstrzymać się od tego, co przeszkadza takiemu oddaniu, choćby ta przeszkoda nie obligowała go według drugorzędnego prawa naturalnego. Druga z podanych racji na to, że niewolnik może zawrzeć małżeństwo wbrew woli pana, nie jest rozstrzygająca, bowiem pewne jest, że nie wszyscy, którzy powinni chronić siebie jako jednostkę, mają pomnażać gatunek ${ }^{32}$. Jeśli ktoś mówi, że w tym przypadku jest mu to co najmniej dozwolone (pomnażać gatunek) i nie może mu być to zabronione przez człowieka, jest to prawdą w przypadku konieczności, w której zachowanie gatunku zależałoby od jego aktu. Jednak ponieważ wielu ludzi wolnych zamierza zrodzenie, także chrześcijan, dlatego ten akt nie jest konieczny dla zachowania gatunku i przez jakieś zobowiązanie można go sobie uniemożliwić3 ${ }^{33}$. To jest potwierdzone, ponieważ przed ślubem niewolnik jest zobowiązany do pewnych aktów, np. a, b, c. Jeśli zawiera małżeństwo,

${ }^{29}$ Por. Jan Duns Szkot, Ordinatio, dz. cyt., nr 27.

${ }^{30}$ Argumentum a simili - wnioskowanie z podobieństwa, argumentacja funkcjonująca już w czasach starożytnych używana przez retorów, filozofów i prawników. Wnioskowanie to polega na badaniu różnych stanów faktycznych (podobnych do siebie) oraz ich uregulowania prawnego, a następnie na przenoszeniu tak wyinterpretowanych norm zachowania się na stany faktyczne nieuregulowane lub których regulacja prawna jest niepełna.

${ }^{31}$ Por. Jan Duns Szkot, Ordinatio, dz. cyt., nr 28.

${ }^{32}$ Por. tamże, nr 30.

${ }^{33}$ Por. tamże, nr 31. 
będzie zobowiązany do czegoś niemożliwego do pogodzenia $\mathrm{z}$ b lub c, dlatego to późniejsze zobowiązanie nie może być sprawiedliwie uczynione, bowiem jest przez nie usuwane inne, którego nie może on wypełnić po takim zobowiązaniu ${ }^{34}$.

Ostatecznie Duns Szkot stwierdza co do tego zagadnienia ${ }^{35}$, że niewolnik z woli pana może zawrzeć małżeństwo i jeśli obowiązki małżeńskie byłyby w czymś przeciwne normalnej służbie, właściciel pozwalający zawrzeć małżeństwo zwalnia go implicite od tej normalnej służby. Jeżeli pan potem odwołałby to zezwolenie przez całkowite uniemożliwienie mu stosunku płciowego albo przez wysłanie go w dalekie strony, albo zajmowanie go w pracach tak, że nie mógłby od czasu do czasu odwiedzać żony, grzeszyłby śmiertelnie i otwarcie (manifeste) powinien być przez Kościół upomniany ${ }^{36}$.

Niewolnik może także zawrzeć małżeństwo, kiedy pan jest temu przeciwny, w takiej mierze, w jakiej ma prawo do swojego ciała, nie pozbawił się bowiem całkowicie wolności co do wszystkich aktów. W takiej mierze, w jakiej jego ciało (corpus) jest jego, może dzielić je z drugim ${ }^{37}$. Niewolnik może zawrzeć związek małżeński z wolną kobieta, jeżeli tylko ona znałaby jego sytuację i zgadzałaby się na nią, bowiem wtedy wymienia (commutat) władzę nad swoim ciałem z taką, jaką ma niewolnik nad swoim ciałem. Niewolnik może zawrzeć małżeństwo z niewolnicą i wydaje się, że każdy z obojga zgadza się na to, co jest w jego władzy, i podobnie jak zawierają małżeństwo, tak są zobowiązani potem według sprawiedliwości oddawać sobie powinności małżeńskie, na ile oczywiście te akty nie przeszkadzają normalnej służbie ${ }^{38}$.

Jednak przypuśćmy, że $\mathrm{w}$ tym przypadku zawierają małżeństwo bez woli panów i jeden z nich posyła niewolnika do Afryki, a drugi posyła niewolnicę do Francji, czy można tak uczynić3 ${ }^{39}$ ? Doctor Subtilis odpowiada: ponieważ małżeństwu należy sprzyjać, należy nakłaniać właścicieli, aby tego nie robili, lecz jeśliby tak się stało, nie jest jasne, że ich postepowanie wobec niewolników przeczy sprawiedliwości, bowiem ten pierwszy był we władzy pana, aby on wysłał go, gdzie chce, a nawet, aby go sprzedał. Podobnie ona była we władzy swego pana, również co do miejsca. Przez własne bowiem akty, bez woli panów, nie mogą siebie czynić wolnymi ani wyzwalać siebie od obowiązków wobec swoich właścicieli. Dlatego rozporządzanie niewolnikiem po jego ślubie nadal jest dozwolone $^{40}$.

Pozostaje jeszcze pytanie: Czy niewolnica ważnie zawiera małżeństwo, jeśli wierzy, że zawiera małżeństwo z wolnym, który jednak jest niewolnikiem? Moż-

\footnotetext{
${ }^{34}$ Por. tamże.

${ }^{35}$ Po dyskusji nad opiniami innych autorów Szkot podaje swoje rozwiązanie.

${ }^{36}$ Por. Jan Duns Szkot, Ordinatio, dz. cyt., nr 32.

${ }^{37}$ Por. tamże, nr 33.

${ }^{38}$ Por. tamże, nr 34

${ }^{39}$ Por. tamże, nr 35.

${ }^{40}$ Por. tamże, nr 36.
} 
na powiedzieć, że błąd co do stanu gorszego (czyli co do stanu niewolniczego) unieważnia umowę, bowiem jest przeszkodą dla zawierającego umowę, aby tyle otrzymać, ile chce wymienić. Jednakże ignorancja co do lepszego albo równego stanu nie uniemożliwia małżeństwa ${ }^{41}$.

Na zakończenie swoich wywodów Duns Szkot odnosi się do głównych argumentów podanych na początku. Jeśli chodzi o pierwszą wątpliwość, zgodnie z wcześniejszą argumentacją jest jasne, że niewolnik nie jest własnością pana stosownie do wszystkiego. W pewnych kwestiach jest on własnowolny, co do jedzenia, picia, spania, krótko mówiąc do wykonywania jakiegokolwiek aktu, dla którego nie są opuszczane posługi należne jego panu. Dlatego, skoro w tym wypadku mógłby praktykować akt cielesny, może do niego siebie zobligować tak dalece, jak dalece jest własnowolny. To, co Arystoteles mówi o tym przeklętym niewolnictwie (servitute illa maledicta), gdzie niewolnik jest jak bydlę (sicut pecus), może być rozumiane tak, że należy on do swojego właściciela jak posiadłość albo pieniądze, nie tak jednak, że w aktach swoich byłby tylko kierowany i nie mógł sam o nich decydować. O ile bowiem jest niewolnikiem, jest także człowiekiem i stąd ma wolną wolę. $\mathrm{Z}$ tego wynika, że w pierwszym wprowadzeniu niewolnictwa było wielkie okrucieństwo, bowiem człowieka o wolnej woli i pana swoich aktów, co do cnotliwego działania, uczyniło jakby zwierzęciem, jakby nieużywającym wolnej woli i niemogącym działać w sposób cnotliwy ${ }^{42}$.

W przypadku drugiego argumentu (porównującego małżeństwo do profesji zakonnej) nie zachodzi tu analogia, bowiem profes w zakonie całkowicie podporządkowuje siebie przełożonym tego zakonu i w tym całkowicie oddala się od służby swemu panu. Nie tak zaś zawierający małżeństwo, lecz tylko w niektórych aktach, które mogą współistnieć z tym, przez co wypełnia on swoją zwyczajną służbę ${ }^{43}$.

\section{ZESTAWIENIE KONCEPCII ŚW. TOMASZA Z AKWINU I BŁ. JANA DUNSA SZKOTA}

Porównując oba teksty o małżeństwie niewolników, można zauważyć, że rozważania św. Tomasza są bardziej przejrzyste, natomiast Ordinatio jest w większym stopniu osobiste i porusza więcej wątków. Tekst bł. Jana Dunsa Szkota jest późniejszy, tworząc go, znał on już Summę teologicznq. Omawiani przedstawiciele szkół średniowiecznych - dominikańskiej i franciszkańskiej - są ze sobą zgodni co do rozwiązania podstawowej kwestii, czyli możliwości zawarcia małżeństwa przez niewolników ${ }^{44}$.

\footnotetext{
${ }^{41}$ Por. Jan Duns Szkot, Ordinatio, dz. cyt., nr 37.

${ }^{42}$ Por. tamże, nr 38-39.

${ }^{43}$ Por. tamże, nr 40.

${ }^{44}$ Por. tamże, nr 37; Tomasz z Akwinu, Suma teologiczna, dz. cyt., q. 52, a. 1.
} 
Średniowiecze było epoką, w której w chrześcijańskich krajach Europy szukano uzasadnień w prawie Bożym i naturalnym zarówno dla wolności osoby, jak i dla jej ograniczeń, przy tym dopuszczano istnienie niewolnictwa. Funkcjonowała bowiem określona interpretacja prawa natury i wynikających z niego uprawnień człowieka. Już Arystoteles pisze, że według niektórych władza pana nad niewolnikiem jest oparta na przemocy. On sam postrzega jednak panowanie „sprawniejszych umysłem” nad „słabszymi” jako wynikające z natury ${ }^{45}$. Natomiast św. Tomasz i bł. Jan Duns Szkot uważają stan niewolniczy za niezgodny z prawem naturalnym. Jak pisze Szkot: „z natury każdy rodzi się wolny”46.

Cytowani scholastycy uznają istnienie takich uprawnień, które dotyczą wszystkich ludzi, zawsze. Podkreślają oni podleganie osoby prawu naturalnemu, ponad prawem stanowionym. Zauważają jednak, że to drugie często jest oparte na prawie naturalnym, stąd nie może być lekceważone. Omawiając prawa przysługujące człowiekowi, Doctor Subtilis odwołuje się do różnicy natur człowieka i innych bytów ożywionych i nieożywionych. Można mówić o negatywnej definicji człowieka w rozważanej kwestii - człowiek nie jest zwierzęciem i nie jest przedmiotem ${ }^{47}$. Nie może on także samodzielnie zmienić swojej natury i stać się bytem innego rodzaju. Żaden stan chorobowy nie może go takim uczynić, żadne przestępstwo, tym bardziej sytuacja utraty wolności. Święty Tomasz wspomina na przykład o trądzie, który nie czyni człowieka niezdolnym do aktów osobo$\mathrm{wych}^{48}$.

Dla Akwinaty i Szkota człowiek nie jest jednak wolny w sposób absolutny, jest to wolność ograniczona jego natura, która będąc źródłem jego praw, ustanawia także obowiązki. Przykładowo, syn ma od ojca byt i naukę i stąd winien mu posłuszeństwo. Granice wolności osoby nie są stawiane arbitralnie, ale wynikają ze sprawiedliwości opartej na naturze osób i ich aktów. U obu autorów widać hierarchię uprawnień wynikających z prawa naturalnego - wolność nie jest w niej ponad sprawiedliwością. Szkot wspomina na przykład, że człowiek nie ma bezwarunkowego prawa do potomstwa ${ }^{49}$. Prawa człowieka kończą się tam, gdzie zaczynają się prawa innych - dlatego sprawujący władzę może odebrać wolność każdemu, kto źle jej używa. Państwo, jego mieszkańcy, mają prawo się bronić, prowadząc m.in. wojnę sprawiedliwą. Święty Tomasz i bł. Jan Duns Szkot dopuszczają (oczywiście w wypadku konieczności) zarówno zabicie napastnika w obronie własnej, jak też karę śmierci. Życie osoby nie ma więc wartości absolutnej, pozostaje ono na służbie określonych wartości.

\footnotetext{
${ }^{45}$ Por. Arystoteles, Polityka, dz. cyt., s. 23-24.

${ }^{46}$ Por. Jan Duns Szkot, Ordinatio, dz. cyt., nr 19.

${ }^{47}$ Por. tamże, nr 38-39.

${ }^{48}$ Por. Tomasz z Akwinu, Suma teologiczna, dz. cyt., q. 52, a. 1, ad. 6.

${ }^{49}$ Por. Jan Duns Szkot, Ordinatio, dz. cyt., nr 30-31.
} 
Z rozważań scholastyków wyłania się obraz człowieka jako istoty społecznej. Rozum umożliwia bowiem człowiekowi nie tylko wolne wybory osobiste, ale też przywództwo, zarządzanie wspólnotą. Ludzie mają predyspozycje do różnych zadań, jak członki jednego ciała. Człowiek inteligentniejszy nie powinien jednak sprawować swej władzy w taki sposób, aby niewolić podwładnych. To panowanie, podobnie jak wolność jednostki, również nie może być nieograniczone. Cytowani autorzy nie stawiają jednostki ponad społecznością ani odwrotnie, ale zachowują tu właściwą równowagę. Osoba ludzka nie jest wolna w sposób absolutny, ale też żadna wspólnota nie ma nad nią nieograniczonej władzy.

Święty Tomasz i bł. Jan Duns Szkot próbują jednocześnie ukazać zarówno wielką godność osoby, jak i uprawnienia społeczeństwa, które może np. sprawiedliwie ukarać najeźdźców karami przymusowych robót. Szkot wyraźnie nie jest jednak zwolennikiem retrybutywizmu ${ }^{50}$. Ktoś, czyja wolność przestała być już zagrożeniem dla innych, powinien ją odzyskać. Osoba zasługuje więc na miłosierdzie mimo dokonanego zła. Człowiek może zbłądzić i nawrócić się, jego godność sprawia, że pokuta przywraca mu prawość. Mimo że Doktor Subtelny zauważa jeden przypadek sprawiedliwego ograniczenia wolności jednostki, czyli zagrożenie innych ludzi (ponieważ samodzielne oddanie się w niewolę uważa za sprzeczne z naturą), to jednak nie pochwala trzymania w niewoli kogoś, kto nie jest już niebezpieczny dla bliźnich. Święty Tomasz także uzasadnia sprawiedliwą karę prawem naturalnym ${ }^{51}$.

Cytowani autorzy dopuszczają możliwość ograniczenia praw małżonków ze względu na sprawiedliwość, wynikającą z prawa natury. Małżeństwo jest jednak prawem każdej zdolnej do niego osoby. Niewolnik może wziąć ślub bez zgody pana. Istnieje bowiem przestrzeń ludzkiej wolności, w którą może ingerować tylko Bóg. Jednak także wtedy musi on spełniać swoje obowiązki służebne, co wynika ze sprawiedliwości. Według obu cytowanych autorów niewolnik nie podlega panu w wielu sprawach: jedzenia, spania, życia, małżeństwa. Jak słusznie zauważa Akwinata, również żona nie może całkowicie zniewolić męża, może on bez jej zgody sprzedać się w niewolę, jeśli nie naruszy to jej dóbr małżeńskich ${ }^{52}$.

Małżeństwu należy sprzyjać. Nie tylko jest to wymagane od Kościoła, ale także od właścicieli niewolników. Mają zostać upomniani przez władzę kościelną, jeśliby przeszkadzali $\mathrm{w}$ funkcjonowaniu małżeństw swoich niewolników, ponieważ opierają się one na wolnym wyborze. Właściciel nie może zmieniać

${ }^{50} \mathrm{~W}$ uzasadnieniu kary kryminalnej kierunek zwany retrybutywizmem akcentuje nie tyle naprawienie zła powstałego w relacjach społecznych, osobie sprawcy i poszkodowanego, ile sprawiedliwą odpłatę należną przestępcy. Por. J. Latała, Od idei odwetu po sprawiedliwość naprawczq. Rozważania nad resocjalizacyjnym charakterem instytucji mediacji po wyroku jako formy sprawiedliwości naprawczej, „Probacja” 2(2010) nr 2, s. 31-32.

${ }^{51}$ Por. Tomasz z Akwinu, Suma teologiczna, dz. cyt., q. 52, a. 1, ad. 3.

52 Por. tamże, a. 3. 
wcześniejszej decyzji aprobującej małżeństwo i potem uniemożliwiać jego funkcjonowania. Byłoby to niesprawiedliwe. Wolny człowiek ma prawo związać się sakramentalnym węzłem, z kim chce, także z niewolnikiem. Najgłębsza godność osoby nie zależy więc od stanu społecznego. Ma ją w pełni nawet ktoś zewnętrznie zniewolony.

Według Akwinaty i Dunsa Szkota przeszkodą w zaistnieniu małżeństwa niewolników jest jedynie brak odpowiedniej świadomości stanu społecznego kandydata na współmałżonka. Wiąże się to bowiem z poważnym ograniczeniem wolności, potrzebnej do podjęcia obowiązków małżeńskich. Można powiedzieć, że prawo do małżeństwa, ale jednocześnie do informacji o narzeczonym, należy do uprawnień każdego człowieka, mającego godność osobową nawet mimo życia $\mathrm{w}$ stanie niewolniczym. Zniewolenie zewnętrzne osoby nie może być przeszkodą dla jej najgłębszych aktów ludzkich, umożliwiających dar z siebie. Jest to zgodne ze współczesną, personalistyczną, koncepcją małżeństwa. Człowiek ma też prawo do posiadania rzeczy. Szkot podpowiada, że konkretne uprawnienie (ius) może być nabyte, jeśli zdarzyłyby się warunki, jakie prawa ustalają, to jest, że ktoś nabyłby coś sprawiedliwie i byłby posiadaczem w dobrej wierze, i że posiadałby to bez przerwy czasowej określonej przez prawo ${ }^{53}$.

Wolność człowieka, oprócz wielu innych aspektów, ma także wymiar moralny. To on jest dla Szkota najważniejszy. Wydaje się, że tradycyjna moralność chrześcijańska e p oki podrę c zników bardziej akcentowała wolność „od” (grzechu) niż wolność „,do” jako drogę do doskonałości ${ }^{54}$. Jednak według Dunsa Szkota wolność człowieka pozostaje na służbie aktów cnót. Nie dopuszcza on sytuacji, którą można by nazwać niewolą moralną, polegającą na sprowadzeniu człowieka do poziomu zwierzęcia i przedmiotu, które nie mogą w sposób wolny wykonywać czynów będących zasługą przed Bogiem. Nikt nie może być w nich ograniczany. To w nich widzi więc Doctor Subtilis coś istotowo ludzkiego. Zdolność do aktów cnót można zaliczyć do pozytywnej definicji osoby. Człowiek jest do nich powołany. Aby je spełniać, ma on wolną wolę oraz światło poznania rozumowego. Świadoma wolność, będąca naturą człowieka, ma prowadzić go do działania dobrego moralnie. Wolność stanowi element transcendencji osoby ku Bogu i bliźniemu, świadczy o godności osoby. Człowiek nie tylko przeżywa dobro lub zło, ale realnie staje się przez wolne czyny - dobrym lub złym. Dlatego sprzeczne ze sprawiedliwością są wszelkie próby jego zniewolenia. Wolność to dar, który Bóg dał i zadał człowiekowi. Wolność jest osadzona w Bogu, wiąże się ze świętością osoby.

\footnotetext{
${ }^{53}$ Por. Jan Duns Szkot, Ordinatio, dz. cyt., nr 25.

${ }^{54}$ Por. J. Grzesica, Wolność jako zadanie (w świetle encykliki Jana Pawła II Veritatis splendor), „Śląskie Studia Historyczno-Teologiczne” 29(1996), s. 201.
} 


\section{ZAKOŃCZENIE}

Scholastyczne rozważania nad małżeństwem niewolników zakładają określoną teologię osoby i jej wolności. Jest to myśl głęboko przeniknięta ideą godności człowieka, a więc personalistyczna, choć św. Tomasz i bł. Jan Szkot nie używają tego terminu. Jest ona zgodna z koncepcją wolności, ukazaną współcześnie tekstem z konstytucji Soboru Watykańskiego II Gaudium et spes: „Człowiek, będąc jedynym na ziemi stworzeniem, którego Bóg chciał dla niego samego, nie może odnaleźć się w pełni inaczej, jak tylko poprzez bezinteresowny dar z siebie" 55 . Jak zauważa K. Wojtyła, cytowany dokument soborowy podkreśla, że czynem najgłębiej rozwijającym człowieczeństwo jest akt bezinteresownego daru miłości z siebie samego. Nie wyczerpuje się on jednak w relacjach indywidualnych, ale ma też wymiar społeczny. Człowiek, działając także wspólnie z innymi, spełnia czyn i spełnia w nim siebie ${ }^{56}$. Niewolnik, jako osoba ludzka, mimo zniewolenia zewnętrznego jest zdolny do daru z siebie w małżeństwie i w cnotliwym działaniu na rzecz innych osób.

Myśl scholastyków jest w pełni zgodna z biblijną teologią wolności. W Piśmie Świętym bycie wolnym to coś innego niż indeterminizm. Oznacza ono bycie dziedzicem, posiadaczem swego bytu, i - co się z tym wiąże - akceptację dla jego relacyjności, a ostatecznie trwanie w miłości. Bóg stworzył bowiem człowieka na swój obraz i podobieństwo. Powołując go do istnienia z miłości, powołał go jednocześnie do jej realizacji. Bóg jest w całej swej istocie bytowaniem „dla”. Wolność człowieka jest obrazem tak rozumianej wolności Boga i upodabnia człowieka do Niego, nie jest wolnością od relacji. Wolność oznacza współistnienie różnych wolności, nie może być zawężona do wolności osobistej ${ }^{57}$. Podobnie cytowani w artykule autorzy, ceniąc wolność, dalecy są od jej absolutyzacji. Do realizacji zobowiązań małżeńskich jest ona konieczna, ale niekoniecznie wolność całkowita, stąd także niewolnik może zawrzeć małżeństwo. Wolność, rozumiana jako wyzwolenie od jakiejkolwiek determinacji, nie jest dla człowieka możliwa.

Zarówno indywidualizm, odrzucający uczestnictwo w działaniu wspólnoty, jak i totalitaryzm, który podporządkowuje jednostkę wspólnocie, faktycznie unicestwiają spełnianie się osoby w czynie ${ }^{58}$. Osoba ludzka nie tylko bowiem przeżywa dobro lub zło, ale realnie staje się przez wolne czyny - dobra lub zła. Dla-

${ }^{55}$ Sobór Watykański II, Konstytucja duszpasterska o Kościele w świecie współczesnym Gaudium et spes (07.12.1965), w: Sobór Watykański II. Konstytucje, dekrety, deklaracje. Tekst tacińsko-polski, Paris 1967, nr 24.

${ }^{56}$ Por. K. Wojtyła, Osoba i czyn, Kraków 1985, s. 335-336.

${ }^{57}$ Por. B. Ferdek, Werytatywne aspekty wolności w ujęciu Josepha Ratzingera, „Studia Gnesnensia" 25(2011), s. 181-187.

${ }^{58}$ Por. I. Smentek, Personalizm teologiczny Karola Wojtyty - Jana Pawła II, „Warszawskie Studia Teologiczne" 27(2014) nr 1, s. 209-211. 
tego sprzeczne ze sprawiedliwością są wszelkie próby uniemożliwienia jej spełniania aktów cnót. Drugi człowiek nie ma prawa zniewalać osoby w tym, co jest istotowo ludzkie, co przysługuje jej jako osobie. Do takich aktów ludzkich należy decyzja o małżeństwie, które bez prawdziwej zgody byłoby nieważne. Osoba ma prawo „stawać się” W wolności poprzez swoje czyny. W tym kontekście wolność jest darem bezcennym.

\section{SUMMARY}

The article deals with the topic of human freedom based on discussions on marriage of slaves of St. Thomas Aquinas and Blessed John Duns Scotus, contained in the Summa Theologica and Ordinatio. Both authors think that a slave can get married even without the consent of its owner. Moreover they indicate that man has no right to absolute freedom, understood as a negation of moral principles and equitable social contracts. On the other hand, no law or person is allowed to restrict certain space of freedom in man thanks to which he can perform acts of virtue as well as decide to get married.

\section{Keywords}

John Duns Scotus, Thomas Aquinas, marriage, slavery, person, freedom

\section{BIBLIOGRAFIA}

Arystoteles, Etyka nikomachejska, w: Dzieła wszystkie, t. 5, tłum. D. Gromska, Wyd. PWN, Warszawa 1996, s. 77-300.

Arystoteles, O niebie, thum. P. Siwek, wyd. PWN, Warszawa 1980.

Arystoteles, Polityka, tłum. L. Piotrowicz, wyd. De Agostini, Altaya, Warszawa 2002.

Cicero Marcus Tullius, O inwencji retorycznej. De inventione, thum. K. Ekes, wyd. IBL PAN, Warszawa 2013.

Digesta Justyniańskie. Księga Pierwsza, tłum. B. Szolc-Nartowski, wyd. Elipsa, Warszawa 2007.

Ferdek B., Werytatywne aspekty wolności w ujęciu Josepha Ratzingera, „Studia Gnesnensia” 25(2011), s. 179-190.

Grzegorz Wielki, Księga reguty pasterskiej, tłum. J. Czuj, WT UAM, Poznań 2009.

Grzesica J., Wolność jako zadanie (w świetle encykliki Jana Pawła II Veritatis splendor), „Śląskie Studia Historyczno-Teologiczne” 29(1996), s. 197-202.

Jan Duns Szkot, Ordinatio, Opera Omnia, t. 13, Typis Vaticanis, Civitas Vaticana 2011.

Latała J., Od idei odwetu po sprawiedliwość naprawczq. Rozważania nad resocjalizacyjnym charakterem instytucji mediacji po wyroku jako formy sprawiedliwości naprawczej, „Probacja” 2(2010) nr 2, s. 28-51.

Raymundus de Pennaforte, Decretales D. Gregorii Papae IX.: suae integritati vna cum glossis restitutae, Romae 1582. 
Smentek I., Personalizm teologiczny Karola Wojtyty - Jana Pawła II, „Warszawskie Studia Teologiczne" 27(2014) nr 1, s. 193-220.

Sobór Watykański II, Konstytucja duszpasterska o Kościele w świecie współczesnym Gaudium et spes (07.12.1965), w: Sobór Watykański II. Konstytucje, dekrety, deklaracje. Tekst tacińsko-polski, Éditions du Dialogue, Paris 1967, nr 24.

Tomasz z Akwinu, Suma teologiczna. Matżeństwo, t. 32, tłum. F.W. Bednarski, wyd. Veritas, Londyn 1982.

Wojtyła K., Osoba i czyn, wyd. Polskie Towarzystwo Teologiczne, Kraków 1985.

Krzysztof Niewiadomski OFMCap, doktor nauk teologicznych. Autor rozprawy Rola komunikacji niewerbalnej w budowaniu relacji międzyosobowych. Aspekt teologiczno-moralny. Wykładowca w Wyższym Seminarium Duchownym Braci Mniejszych Kapucynów w Krakowie. Duszpasterz farmaceutów archidiecezji krakowskiej. 